SHS Web of Conferences 10, 00029 (2014)

DOI: $10.1051 /$ shsconf/20141000029

C Owned by the authors, published by EDP Sciences, 2014

\title{
Assignment in a variable economic situation
}

\author{
V. Nemenova \\ Riga Stradiņš University, Latvia
}

\begin{abstract}
Claim transmission from one creditor to another (assignment), due to the development of business in Latvia, becomes more and more important. The assignment is a unique as well as universal institute of private rights, which role is difficultly to overvalue for normal economical turnover, nevertheless the legislator, on accepting the Civil Law of 1937, has not envisaged all nuances in the area of the legal regulation of the assignment in the variable economic situation. The author makes a conclusion that it is necessary to develop specific recommendations for perfection of the Civil Law's legal standards in Latvia, by analyzing the legal acts, judicial practice of Latvia and other countries, and the works of the legal scientists within the sector of cession's legal regulation.
\end{abstract}

\section{Introduction}

The aim of the article is to analyze the substantial moments of cession's legal regulation in Latvia and to define the directions of modernization of cession's legal regulation in Latvia. During the last 10 years, in Latvia, a new type of business, debt collection, has been created and it functions. In many cases, conclusion of an assignment contract becomes economically convenient. In the early nineties of the last century Latvia had renewed her independence and started the transfer from command economy to the modern market economy. The renewal of independence of Latvia came along with some great changes in the legislation field. In the time period from 1992 till 1993, the activity of Latvian Civil Law adopted on January 28th, 1937, was renewed. Unfortunately, the Civil Law of 1937 was not a collection of new legal norms, but only a collection of legal views of previous centuries, since the Civil Law was based on the Roman law, the Napoleonic Code, as well as some older normative acts.

Amendments made in Latvian Civil law within the time period from 1992 up to now have not effected legal norms regulating the assignment of the claim rights and in Latvian legal theory there have not been fundamental researches on this theme up to now.

\section{Materials and methods}

In the paper, the Civil Law of Latvia is analyzed; the attention is drawn to the conclusions of legal scientists of Latvia and other countries within the sector of cession's legal regulation. The analytical and comparative science study methods have been used in the paper.

This is an Open Access article distributed under the terms of the Creative Commons Attribution License 4.0, which permits unrestricted use, distribution, and reproduction in any medium, provided the original work is properly cited. 
SHS Web of Conferences

\section{Results}

It is necessary to develop specific recommendations for perfection of the Civil Law's legal standards in Latvia, by analyzing the legal acts, judicial practice of Latvia and other countries, and the works of the legal scientists within the sector of cession's legal regulation, by implementing the first duty on the assignee to inform the debtor within the defined term about the concluded cession (assignment) agreement, to specify non-assignable claims, as well; as to exclude the collection of penalty arising from the claims, which have been received basing on the cession agreement.

\section{Discussion}

The Civil Law of the Republic of Latvia defines the following cession foundations:

1) in compliance with law, without the prior expression of creditor's will;

2) in compliance to the court decision;

3) according to the legal deal, regardless of whether the creditor had concluded it pursuant to the law or voluntarily (Civillikums, 1937).

In practice, in most cases claim rights cessions on the basis of legal deals are used, but one should not underestimate such foundations of claim rights cessions as law and court decision. There are always three persons involved in any cession: the debtor, the former creditor (cedent) and the new creditor (assignee).

While examining the general conditions of contracts, the order of their conclusion, implementation, termination and invalidation, the Western authors mention the principle of contract freedom, that is, the freedom of its conclusion and content development at its parties' discretion.

The principle of contract freedom is the most important feature of private autonomy. The contract freedom means that the parties can form contractual relationships and define the content of the contract on the grounds of mutual understanding and free choice.

USA Law about obligations is based on the principle expressed in Part 10, Article 1 of the Constitution, according to which, the state shall not pass any law impairing the freedom of contracts. But in practice, in USA, as well as in any other country, the freedom of contract rights is limited by the law. In the USA law, the issues of obligations are included into the Uniform Commercial Code (Bojārs, 1998).

In the laws, one can find certain cases when cession is not allowed, for instance, when its possibility was precluded in accordance with an agreement concluded by the former creditor and the debtor, when the obligations towards the new creditor can not be made without the contract amendment, if nonassignable obligations are related to the payment of court-inflicted penalty etc. (Коллектив авторов, 2004).

USA court practice and law have significantly simplified the implementation of claim cession by rejecting the medieval norms that so far had an effect upon the English law. The Uniform Commercial Code of the USA followed the acknowledgement of cessions as it is implicated in the laws of continental European states. In Article 2-210 it is stated that all seller or buyer's rights can be assigned, except the cases when such a transfer lan result in significant changes in obligations of on' of the parties or a significant increase of burden or risk (Коллектив авторов, 2004).

The Latvian Civil Law determines exceptions for claims that can not become cession subjects, namely:

1) all claims, whereof the implementation, either as a result of parties' agreement, or pursuant to a law, is related to the creditor;

2) claims, the content of which would significantly change in case of their transfer to any other person apart from the real creditor (Civillikums, 1937). 


\section{Int. Conf. SOCIETY. HEALTH. WELFARE.}

Item 1, Article 1799 of the Civil Law says that non-assignable are claims which, according to the parties' agreement, are part and parcel of the creditor. Already in 1914, Bukovsky wrote: doctrinally disputable question, whether the parties can, by mutual agreement, exclude from legal circulation claims that one contracting party has towards the other, is being solved by law positively, since a debtor can be strongly interested in low probability of claim cession to other persons (Буковский, 1914). Such debtor's preference can be substantiated by the fact that usually a cession pursues for the assignee's speculative aims, since, by purchasing the claim for a price that is lower than nominal, he hopes to recover from the debtor a greater sum (Де ла Морандьер, 1960).

Claims that are part and parcel of the creditor and, therefore, can not be assigned, include, for example, parental rights to demand maintenance from their children: The aforementioned parental claim right can not be assigned even if there is children's consent to such a cession (Буковский, 1914). A. Grūtups points that one should accept this opinion and to include into the list of non-assignable claims children and parents' (grandparents') mutual maintenance claims, as well as former spouses' mutual maintenance recovery claims (Autoru kolektīvs, 2000).

However, the list of the rights excluded from circulation is not comprehensive. The claims for providing lifetime support are also could be referred to that. The interesting question about the possibility of assignment of rights of claim for the compensation of non-pecuniary damage arises. There are cases, when the compensation for non-pecuniary damage is required due to damage to the honor and dignity, and in other cases, and not in connection with direct health damage.

A. Erdelevskiy considers that claims for compensation for non- pecuniary damage are not connected with adverse changes of property status of residents, and is not directed to its recovery, loss of this right can not create adverse change for other persons, therefore there is no basis for exemption of the right for compensation for non-pecuniary damage from the circulation (Эрделевский, 1998).

Conversional issue is the issue about the presence of a provision of confidentiality in the agreement, what puts a person of creditor in a frame of significant importance.

Provisions of confidentiality determining importance of a person of creditor for a debtor, shouldn 't be treated widely. An individual approach should be found for each case, it is necessary to take into consideration the nature of relations, peculiarities of their legal status etc. Moreover, a debtor, who is interested in, must prove the essentiality of the importance of creditor itself.

Convention UN about assignment of receivables in international trade contains provisions specifying that a creditor, without reference to provisions of any agreements, has the right to give up his receivables subsequently, and it means absence or inefficiency of any obstacles as a provision of confidentiality of the agreement for entering into a cession agreement.

Civil obligation lets to attribute the property right, including the contractual rights, to objects of the civil rights. Moreover, the legislator distinctly determines that the assignment of rights is possible in respect of the rights of claim resulting from the obligation. In this connection, it is impossible to transfer the property rights and other real rights, exceptional rights and other rights, which can not be attributed to the category of subjective contractual rights in a procedure of cession. The legislation does not make distinction between the assignment of rights in contractual and non-contractual obligations. Therefore, all obligations are ready for change of creditor, so there is no difference for a debtor to whom he must pay. Taking into account that there are different bases for circumstances arising, we can make conclusion that delictual and condictional obligations can be transferred to the other person under a cession agreement.

In Article 383 of the Civil Code of the Russian Federation, unlike the Latvian Civil Law, it is clearly defined that it is unacceptable to assign to another person rights that are part and parcel of a creditor, for instance, maintenance rights and reparation of life or health damages (Гражданский кодекс Российской Федерации, 1995).

Article 2245 of the Civil Law says that the claim rights of one member towards another granted by the society contractual relationships, are non-assignable. Non-assignable as well are rights of 


\section{SHS Web of Conferences}

redemption, since the holder of rights of redemption can not pass this right to anyone else and, if an opponent asks so, he/she has to put his/her signature to confirm that the redemption if being made only for his/her sake (Autoru kolektīvs, 2000).

The author believes that two aforementioned cases of cession limitations have become obsolete and do not correspond to the modern needs, since, as Čakste said in 1937, modern law considers the obligations as a property (Čakste, 1937) and nowadays limits, most of all, private autonomy and property disposal rights of any given person.

During the last decade a new type of business - debt collection - has been formed and functions in Latvia. A number of firms working in this type of business in Latvia becomes more and more significant. The most prominent companies are SIA "Creditreform Latvia", SIA "Lindorf”, SIA "Julianus inkasso", SIA "Paus Konsults". Any person - both physical and legal - can act as a debt collector. The collection of debts is a service for the performance of which the creditor concludes an contract with the debt collector.

By its legal nature, any contract is a deal that binds the compliance of will expressed by two or more contracting parties (Зенин, 2009). Usually this contract can be qualified as a contract of engagement (a contract for the performance of a certain paid task), but cession contracts concerning the transfer of claim rights from a previous creditor (an assignor; in most cases - a credit institution) and a new creditor (an assignee - a debt collector) are also very popular. Since, according to Article 1806 of the Civil Law, a claim is being passed to the assignee with all accompanying rights, if there are no exceptions from this regulation applicable to them, at the moment of conclusion of a contract of cession, the assignor can mark various exceptions, in accordance with which, the assignee will have only some certain rights that accompany a claim. Therefore, if a contract of cession makes no provision of such exceptions, we can believe that a claim can be passed with all accompanying rights (Autoru kolektīvs, 2000).

The debtor's status should not become worse after a cession, and the assignee can not apply any of the advantages that he may have over the debtor (Civillikums, 1937). Greater sums recovered from the debtor are often related with penalty calculation and too late assignee's report about the transfer of claim rights.Penalties are often used in Latvian contracts and penalty recovery disputes are often considered in courts. Sometimes court-conferred penalty sums are too big, much more substantial than a debt itself. Penalty volume, especially when expressed in percents per each day of arrears, can prove to be so big that its payment can ruin the debtor economically (Torgāns, 2006).

The issue of fairness of a fine and its commensurability with the severity of the committed violation made is not specially regulated in the Latvian legislation and is not yielding to regulation either. At the time when Latvia has joined the European Union and is integrating in the common economic space, the laws of the EU countries, i.e., such European law unification projects as the UNIDROIT Principles of International Commercial Contracts, have become better-known. The referred unification documents, having no effect as a source of law, nevertheless expressing conclusions of authoritative scientists, contain a provision that upon a party's request a court may decrease a fine if it is excessive, as well as take into considerations other conditions. The UK (England) law carries negative attitude towards the idea of administration of punishment in the private law. The entitlement of courts to decrease excessive fines is incorporated in the legislation of Germany, France, Russia, Lithuania, Estonia, and other countries.

In June 2009, the Civil Law was supplemented by the Article 1724.1, which came into effect on July 1, 2009: "The penalty sufferer may request to decrease the demanded penalty until a reasonable amount, if it is too excessive, comparing with the losses caused by failure of performance or unduly performance or taking other circumstances into account. If the parties have agreed that the penalty payment releases the sufferer of this punishment from interest and yield due from him, as well as from the loss compensation, then the decreased penalty amount must not be less than the losses caused to the other party". Actually the possibility of penalty decrease and the amount has been fully delegated by the law to the court, which, according to the author's opinion, cannot be justified in all cases, because 


\section{Int. Conf. SOCIETY. HEALTH. WELFARE.}

during the procedure of judgment making, the judge's biased opinion cannot be excluded (Civil Law. Chapter four. Law of obligation, 1937, Article 1724.1).

\section{Conclusions}

Usually a cession pursues for the assignee's speculative aims, since, by purchasing the claim for a price that is lower than nominal, he hopes to recover from the debtor a greater sum.

The author concludes that it is necessary to analyze Latvian and other countries' legal acts, court practice and scientists' works in the field of cession regulation, to develop some suggestions for the amelioration of Civil Law norms and, first of all, to oblige assignees to timely inform debtors about concluded contracts of cession. The author believes that it is necessary to specify the nonassignable claims, thus expanding the circle of the assignable claims, as well as to exclude the penalty in indebtedness collection based on the cession agreement, protecting the debtor and excluding for the assignee excessive possibility of profit.

\section{References}

[1] Autoru kolektīvs (2000) Latvijas Republikas Civillikuma komentāri: Ceturtā daļa. Saistību tiesības. [Comments of the Civil Law of the Republic of Latvia: Chapter four. Law of obligation] Rīga: Mans İpašums (in Latvian).

[2] Bojārs J. (1998) Starptautiskās privāttiesības, [International private law] Apgāds Zvaigzne ABC (in Latvian).

[3] Буковский В. (1914) Сводъ гражданских узаконений губерний Прибалтийслих т.2. [Collection of civil statutes of the Baltic provinces ] Рига (in Russian).

[4] Civillikums.Ceturtā daļa. Saistību tiesības (1937) [Civil Law. Chapter four. Law of obligation] Latvijas Vēstnesis,Ziņotājs, 1, 14.01.1993.Stājās spēkā ar 01.03.1993. (in Latvian)

[5] Čakste K. (1937) Civiltiesības [Civil Law], Rīga (in Latvian).

[6] Де ла Морандьер Ж. Л. (1960) Гражданское право Франции [Civil Law of France] т .2, Москва (in Russian).

[7] Эрделевский А. (1998) Компенсация морального вреда третьим лицам [Compensation of moral damage to the third persons] Законность 1998 №2 (in Russian)

[8] Гражданский кодекс Российской Федерации (1995). [Civil Code of the Russian Federation] Москва. www.interlaw.ru/law/docs/10064072/10064072-001.htm. (in Russian)

[9] Коллектив авторов (2004). Гражданское и торговое право зарубежных государств. [Civil and Trade Law of the foreign countries] Москва, «Международные отношения» (in Russian).

[10] Torgāns K.(2006) Saistību tiesības 1.daļa.[Law of obligation] Rīga (in Latvian)

[11] Зенин И.А. (2009) Гражданское и торговое право зарубежных стран. [Civil and Trade Law of the foreign countries ] Москва, Юрайт. Высшее образование (in Russian) 